\title{
Innovation and Growth Dynamics in Sub-Saharan Africa
}

\author{
Alhassan Tijani Forgor ${ }^{*}$ Kouadio Ahou Julie
}

\author{
Peoples' Friendship University of Russia, Moscow 117198, Russia \\ Email: atijaniforgor@yahoo.com
}

\begin{abstract}
This paper examined the relationship between financial innovation (mobile banking) variables of sub-Saharan Africa. Mobile banking (also known as mobile money) is a major financial innovation in the sub-Saharan region, and the system serves a medium through the unbanked and underbanked residents get financial services. The overall importance of financial innovation in the current digital and knowledge-based economy, for that matter innovation development inspired this study. Using partial linear regression model, a dataset from the International Monetary Fund (IMF), World Bank National Economic data and the mobile banking data were explored from GSMA for the period between 2011 and 2017 were analyzed. A negative correlation was found between the mobile money variables and growth as well as financial development, however, a positive relationship was established between financial development and growth. This positive link again supports the position that financial development influences economic growth. It is encouraged that policymakers develop and implement the necessary policy instruments capable of facilitating this form of financial innovation, and thus link its benefits with the national economy in general.
\end{abstract}

Keywords: innovation, financial innovation, growth, financial development, mobile banking, mobile money, sub-Saharan Africa

\section{INTRODUCTION}

In the world today, innovation, as political tool, is considered as a way of solving different economic and social challenges, especially in sub-Saharan African countries where there is a relatively political stability. The political atmosphere has strengthened over the past decade, which has facilitated change of governments through democratic elections in region. Thus, the continent is poised in ripping the benefits of this stability through science and technology (ST) and innovation (I) activities capable of addressing challenges faced by the region. Also, institutions are set up to collaborate and address common problems as well as develop constructive international partnerships, and to respond to the expectations in the African continental free trade area. A substantial technological transformation in Africa, in terms of financial innovation and innovation development in general would help achieve the objectives of this free trade area.

Financial innovation and its impact on economic growth and development can be traced to the work of Schumpeter (1934) [1], who first brought the idea of the link between an economy's innovation performance and the functioning of its credit and capital markets. The relationship between finance, innovation, and economic growth can best be understood through insight into the character of innovation
(Mazzucato, 2013) [2]. Financial innovation, by nature, is considered strategic. Costanzo et al. (2003) [3] thinks that the value of a specific form of financial innovation is determined by its sustainability in the financial sector, thus its value is measured by the extent through which it can be sustained in the market. Thus, it is paramount to identify the type of financial innovations that associate with different development processes in regards with activities, formality and cross-functional involvement including performance outcomes. Thus, financial innovation is considered the link between the financial sector and sustainable development. Financial innovation involves the development and expansion of financial products and services, the introduction of new processes, as well as the interaction with clienteles and the development of new financial structures and institutions. The ability of innovation to create intangible and tangible social changes makes it a key driving force for sustainable development, socioeconomic inclusion and political stability. It worth noting that innovation can reduce the gap of competitiveness, and the knowledge gap between the advanced and developing economies.

This paper takes a novel approach by analyzing the relationship between growth, financial development and financial innovation (mobile money), an in-depth development trajectory of financial innovation and payment system in sub-Saharan Africa. This study outlines 
the importance of country-based approach in defining, developing and creating NISs with very limited STI resources, the way forward in avoiding the likely discrepancy between related strategies and practices. These challenges the required attention of NIS on smart specialization via policies like place-based economic diversification with the help of unique resources, features and the comparative advantages in those communities or countries (Boschma, 2015) [4], especially in the allocation of financial resources.

\section{LITERATURE REVIEW}

Knowledge creation and well-established national innovation system (NIS) are critical drivers of socioeconomic development in the most advanced countries (Tödtling et al., 2013) [5]. Thus, Edquist (2005, p. 182) [6] thinks that the concept and development of a NIS is seen as the cooperation of all economic, political, organizational, institutional, and social factors, together with all other factors that influence the generation, development, diffusion, and implementation of innovations, and this has therefore become a recent policy instrument in developing economies to facilitate their transformational change.

Despite the growing prominence of NIS globally, however, the development and application of innovation policies in third world economies is not adequately studied. Scanty studies have attempted to scrutinize the NIS in-depth and their generation in developing economies, and some studies are often confusing in terms of the terminologies adopted, hence are more often contradictory and misleading. For instance, Watkins et al. (2015) [7] posits that some analyses conducted on economies like South Korea, Taiwan, Brazil, and China are mostly labeled "developing countries" rather than "developed" middle-income and BRICS countries, which thus gives a different impression and understanding. Scholars such as Muchie et al. (2003) [8], and OyelaranOyeyinka (2014) [9] emphasize that very little attention is given to the creation of NIS in poorer or third world economies such as those in sub-Saharan Africa. Also, Bartels \& Koria (2014) [10] and Yun et al., 2015 [11] posited that substantial differences exist among developing economies in terms of their socioeconomic contexts and their capacity to advance to the level of well-established knowledge-based economies.

Furthermore, policy transfer becomes a problem with respect to NISs, as many innovation scholars espoused that the imitations of fruitful and effective innovation policies of advanced economies usually do not yield adequate results in developing economies (Asheim et al., 2011) [12], although innovation and technology policies are continuously transferred from advanced to developing countries. Thus, Daka \& Toivanen (2014) [13] in their work highlight the need for substantial emphasis on research and development (R\&D) and science, technology and innovation (STI) modes of innovation in developing countries. A couple of studies have been carried on financial system-growth nexus with diverse results. Though, scanty of these studies have focused on issues concerning financial innovation. A negative relationship was revealed between financial innovation and money demand by Dunne and Kasekende (2016) [14] after examining the progress of financial innovation and its effect on money demand in sub-Saharan Africa using panel data of 34 countries for the period 1980-2013. This is suggestive that financial innovation serves as a crucial factor in explaining the situation of money demand in subSaharan Africa and, may have significant effects on future policy design. Domeher, Frimpong and Appiah (2014) [15] scrutinized the factors that influence the adoption and implementation of financial innovation in Ghana's banking industry, where Surveys involving over 400 customers of the six major banks were carried out. Logistical regression was applied, which reveals that innovation features like absence of complexity, compatibility and expected efficacy provided by financial innovation, promote the possible adoption of e-banking.

Also, the link between bank competition, financial innovations and economic development in Ghana was analyzed by Anthony and Aboagye (2014) [16] with the help of quarterly data between 1990 and 2009. The application of ARDL co-integration procedures indicated that bank competition is positively linked to economic development in the long-run, whereas financial innovation has a negatively relationship with economic development. Furthermore, bank competition is negatively associated with economic growth, in the short run however, financial innovation is positively correlated to growth for the same period. The outcome also exhibited that unidirectional Granger causality exists between bank competition and growth. On the other hand, bidirectional Granger causality exists between financial innovation and growth. Thus, the need for regulations toward a further competitive banking system with additional innovative products geared toward savings and investment mobilization and allocation to more effective sectors of the economy is encouraged.

It has been established that significantly lower corporate loan spreads are charge banks with greater gross positions in credit derivatives, while the net positions of banks are not constantly associated with the pricing of loans (Norden, Buston and Wagner, 2014) [17]. Also, banks with larger gross positions in credit derivatives during the crisis cut their lending by less than other banks and have continuously lowered loan charge-offs. The outcome of the study is suggestive of important risk management benefits from financial innovations under adverse conditions.

Various studies offer descriptions of a substantial shift in the development and growth dynamics of African economies. For instance, McMillan and Rodrik (2011) [18] outlined the degree of structural change contributions to the overall productivity growth, specifically via export shares, competitive against undervalued exchange rates and the level of labor market flexibility. Particularly, 
sector dynamics are usually very vital, while large compositions of natural resource exports caused a growthreducing structural adjustment, whereas competitive exchange rate managements and labor market flexibility brought about growth-enhancing structural transformation (McMillan and Rodrik 2011) [18]. In a similar study to the above, where the Africa Sector Database were drawn to examine the implications of structural change for productivity growth in some sub-Saharan economies over a period of 1960-2010 by De Vries et al. (2012) [19], highlighted dissimilar results for the different region, and it was observed that patterns of static productivity gains in African economies have similarities to those of Latin America, which however, differ from the Asian experience.

One of the unusual analyses of structural transformation in African economies is a study on Nigeria's economy, which outlines outstanding structural transformations from 1996 to 2009 period in Nigeria, where labor transformed from low productivity agriculture and low value-added trade practices into production or manufacturing, transportation and services, though the contribution of manufacturing to GDP is low (Adeyinka et al. 2013) [20]. Some other authors establish prevalent growth across African economies, which supports much of the earlier empirical outcomes on structural transformation studies by ACET (2014) [21] and McKinsey Global Foundation (2012) [22]. Unlike growth, which previously was often observed to be concentrated on or revolve around a particular and/or some few resources such as oil and agriculture products, the current transformational growth in African economies tends to cut widely across various sectors. There are six notable sectors: agriculture, infrastructure/utilities investment, trade, resources, finance, and telecommunications are seen to be undergoing significant growth and have composed about $83 \%$ of the overall growth based on their contribution to GDP. Since the year 2000, the financial and telecommunications sectors have been identified to be the best performing sectors in sub-Saharan African economies and, these sectors have witnessed the steadiest growth in the region. Nevertheless, very little is known on the current growth of these sectors and how deep and sustainable this growth will be over time, and as revealed, some specific sectors are observed to be driving growth. Africa remains connected to the world market primarily as a supplier of raw materials like petroleum oil and minerals, which has increased more than four times since the year 2000. But, while the effect of this growth dynamics may be not be easy to unravel, its implications, pertaining on the structural transformation and NIS study is that this could be growth-inducing, though country-specific researches would present fairer perspectives.

It has, however, been established that African manufacturing businesses face the risk of losing markets if these firms tend to enter a competition with imports from their Asian counterparts. Thus, this leads the terms and volume of trade including the export destination of raw materials being shifted, with African economies currently deriving much of its economic growth from exporting to Asia.

Furthermore, it was emphasized that financial intermediaries might indeed boost investment in innovative entrepreneurial activities. The connection between banking, financial system and economic development was examined by Hao and Hunter (1997) [23], where a cross-country regression model was constructed using data of the periods 1970-1988. This helped extend the existing literature by explicitly analyzing the effects of measures of an economy's financial deepness, a form of second stage financial innovations, on a country's rate of economic growth. It was found that financial development is positively correlated with improved economic development.

\section{DATA AND METHODOLOGY}

Using the partial linear regression, we analysed the data explored from the GSMA [24] and World Economic Indicators [25] for the period between 2011 and 2017. Financial development index, annual mobile money value and the annual volumes mobile money constituent the variables used in this study. The table 1 below defines the understudied variables. In figure 1 and 2 , the trends of mobile money development as a form of innovation in the financial sector.

To identify the determinants of mobile money/banking and financial development in sub-Saharan Africa the following model was used:

$\mathrm{FD}=\beta 0+\beta 1(\mathrm{FD}) \mathrm{i}+\beta 2($ Eff) $\mathrm{i}+\beta 2($ Perform $) \mathrm{I}+\beta 2($ Av.R) $\mathrm{i}$ $+\varepsilon i \quad(1)$

The model equation was applied along with other statistical techniques to achieve the objective this paper to determine or establish the link between the variables defined below. 
Table 1 Definition of variables

\begin{tabular}{|c|c|l|}
\hline Variable & Code & \multicolumn{1}{c|}{ Definition } \\
\hline $\begin{array}{c}\text { Financial } \\
\text { development } \\
\text { Index }\end{array}$ & FD & $\begin{array}{l}\text { Financial development is a blend of depth (size and liquidity of markets), access (ability of individuals } \\
\text { and firms to get financial services), and efficiency (availability of financial services at low cost and } \\
\text { with sustainable revenues, and the extent of capital market activities). }\end{array}$ \\
\hline Effectiveness & Eff. & $\begin{array}{l}\text { This is the amount (in US dollars) that is presumably contributed yearly by each individual mobile } \\
\text { banking service provider. Simply, it is annual mobile money value divided by the number of } \\
\text { registered agents }\end{array}$ \\
\hline Performance & Perform & $\begin{array}{l}\text { This entails the overall of number of transactions or services undertaken by individual agents of } \\
\text { mobile banking per annum. That is the annual volume operations transacted per active agent. }\end{array}$ \\
\hline $\begin{array}{c}\text { Average of } \\
\text { returns }\end{array}$ & Av.R & $\begin{array}{l}\text { This is the value per transaction. Thus, it is calculated by dividing the total value (in US dollars) or the } \\
\text { overall volume mobile money services provided. }\end{array}$ \\
\hline \multicolumn{2}{|c|}{ Here }
\end{tabular}

Here, we summarily defined the four (4) indicators used for our model analysis. These indicators were determined solely by the authors using data from the GSMA and World Economic Indicators.

In figure 1, we illustrated the volume and value of mobile money transactions in the SSA region.

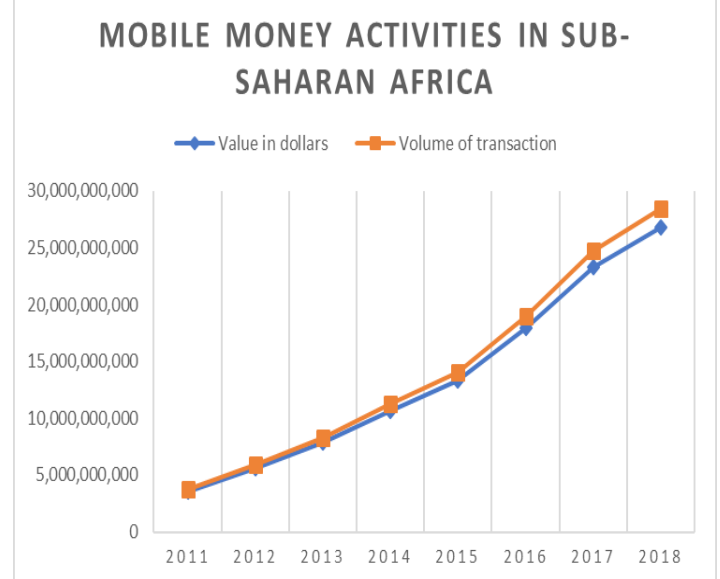

Figure 1 Volume and value of mobile banking operations in SSA region.

As can be seen the diagram above, there is a positive growth tendency of mobile money services, thus there is a continuous rise in annual volume and value of mobile money activities in the region. The agents facilitating the operations mobile banking are presented in the figure 2 below.

Table 2. Descriptive statistics

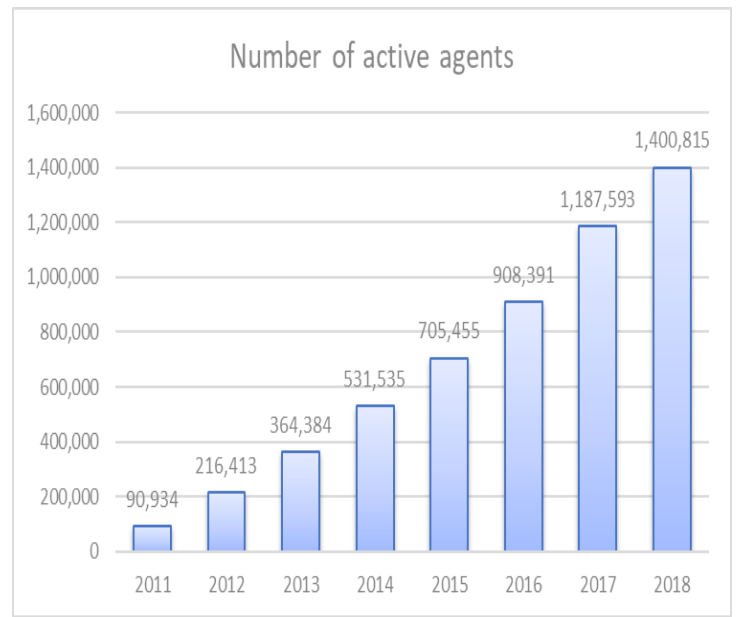

Figure 2 Number mobile banking agents

As can be observed in figure 2 , the res is a continuous rise in the number of mobile money agents in the region, which may be have resulted from the rise in patronage or demand for this innovation in the financial sector.

The above data including others were computed and analysed thoroughly with the help of the model defined in Eq. (1). The results are presented and discussed in the results and discussion section.

$\Phi$

\begin{tabular}{|l|c|c|c|c|c|}
\hline Variable & Obs. & Minimum & Maximum & Mean & Std. deviation \\
\hline GDP per capita & 6 & 3349.328 & 3880.322 & 3649.695 & 214.497 \\
\hline Effectiveness & 6 & 11003.883 & 22928.620 & 14151.067 & 4521.185 \\
\hline Average returns & 6 & 15.570 & 20.617 & 18.789 & 1.882 \\
\hline Performance & 6 & 18829.305 & 39238.415 & 24168.294 & 7812.086 \\
\hline Financial dev. index & 6 & 0.144 & 0.164 & 0.153 & 0.007 \\
\hline
\end{tabular}

Source: Authors' computation using data from GSMA [24] and WDI [25], 2019. 


\section{RESULTS AND DISCUSSION}

The results from this study are a presented in tables and are discussed accordingly. The results are presented in the form of tables.
The table 3 below presents the coefficients of correlation between the variables employed in this study.

\section{Table 3 Correlation matrix}

\begin{tabular}{|l|c|c|c|c|c|}
\hline & Effectiveness & Average returns & Performance & Financial dev. Index & GDP per capita \\
\hline Effectiveness & $\mathbf{1}$ & $0.608^{* *}$ & 1.000 & -0.737 & -0.865 \\
\hline Average returns & $0.608^{* *}$ & $\mathbf{1}$ & $0.609 * *$ & -0.956 & -0.839 \\
\hline Performance & 1.000 & 0.609 & $\mathbf{1}$ & -0.744 & -0.872 \\
\hline Financial dev. index & -0.737 & -0.956 & -0.744 & $\mathbf{1}$ & $0.953^{* *}$ \\
\hline GDP per capita & -0.865 & -0.839 & -0.872 & $0.953^{* *}$ & 1 \\
\hline
\end{tabular}

From the table above, it can be observed that negative correlation was recorded between the dependent variable (GDP per capita) and all the other control variables except financial development, which was found to have a positive relationship with the proxy variable for economic growth.
The model parameters and analysis of variation statistics are presented in table 4 . The analysis of variation and model parameters indicates the overall significance of our model, and the results therein prove the reliability and credibility of our model.

Table 4 Model and analysis of variation parameters

\begin{tabular}{|c|c|c|c|c|c|c|}
\hline Source & DF & \multicolumn{2}{|c|}{ Sum of squares } & $\begin{array}{c}\text { Mean } \\
\text { squares }\end{array}$ & $\mathrm{F}$ & $\operatorname{Pr}>F$ \\
\hline Model & 4 & \multicolumn{2}{|c|}{230042.187} & 57510.547 & 28495.393 & 0.004 \\
\hline Error & 1 & \multicolumn{2}{|c|}{2.018} & 2.018 & & \\
\hline Corrected Total & 5 & \multicolumn{2}{|c|}{230044.205} & & & \\
\hline Source & Value & Std. error & $\mathrm{T}$ & $\operatorname{Pr}>|t|$ & $\begin{array}{c}\text { Lower bound } \\
(95 \%)\end{array}$ & $\begin{array}{c}\text { Upper bound } \\
(95 \%)\end{array}$ \\
\hline Intercept & -13136.515 & 85.295 & -154.013 & 0.004 & -14220.29 & -12052.73 \\
\hline Effectiveness & -0.593 & 0.005 & -120.715 & 0.005 & -0.655 & -0.531 \\
\hline Average returns & 206.559 & 1.239 & 166.768 & 0.004 & 190.821 & 222.297 \\
\hline Performance & 0.348 & 0.003 & 118.649 & 0.005 & 0.311 & 0.385 \\
\hline Financial dev. index & 84376.718 & 398.05 & 211.974 & 0.003 & 79318.99 & 89434.44 \\
\hline
\end{tabular}

The analysis of the fitness of the model is established based model parameters and analysis of variation parameters. The p-values $(0.004)$ indicate the reliability and the significance of the model, while the $\mathrm{R}$ and $\mathrm{R}$ squared values (both recorded 100\%) prove the significant relationship between economic growth the other

\section{CONCLUSION}

This study took a varied and novel approach to establish the impact of financial sector innovation in developing independent and control variables used in this study. Also, the t-values test the hypothesis of confidence level and defined the level importance of each indicator used, in this case all the variables employed in model are very most important and are fit to be used as explanatory factors of growth. countries, particularly in sub-Saharan Africa. Mobile banking data was used to proxy for financial 
[8] Muchie, M., Gammeltoft, P., \& Lundvall, B. (Eds). (2003). Putting Africa First: The Making of African Innovation Systems. Aalborg University Press, Aalborg, Denmark, pp. 361

[9] Oyelaran-Oyeyinka, B. (2014). The state and innovation policy in Africa. African Journal of Science, Technology, Innovation and Development, vol. 6, 481496.

[10] Bartels, F., \& Koria, R. (2014). Mapping, measuring and managing African national systems of innovation for policy and development: The case of the Ghana national system of innovation. African Journal of Science, Technology, Innovation and Development, vol. $6,383-400$.

[11] Yun, J., Won, D., Hwang, B., Kang, J., \& Kim, D. (2015). Analyzing and simulating the effects of open innovation policies: Application of the results to Cambodia. Science and Public Policy vol. 42, 743-760.

[12] Asheim, B., Boschma, R., \& Cooke, P. (2011). Constructing regional advantage: Platform policies based on related variety and differentiated knowledge bases. Regional Studies, vol. 45, 893-904.

[13] Daka, E. \& Toivanen, H. (2014). Innovation, the informal economy and development: The case of Zambia. African Journal of Science, Technology, Innovation and Development, vol. 6, 243-251.

[14] Dunne, P. J., \& Kasekende, E. (2016). Financial innovation and money demand: Evidence from SubSaharan Africa. School of Economics Macroeconomic Discussion Paper Series 2017-06, School of Economics, University of Cape Town, pp. 24.

[15] Domeher, D., J M Frimpong, J.M., \& Appiah, T. (2014). Adoption of financial innovation in the Ghanaian banking industry African Review of Economics and Finance, vol. 6(2), pp. 88-114

[16] Anthony, A. I., \& Aboagye, Q.Q. (2014). Bank competition, financial innovations and economic growth in Ghana. African Journal of Economic and Management Studies, vol. 5(1), 30-51.

[17] Norden, L., Buston, C. S., \& Wagner, W. (2014). Financial innovation and bank behavior: Evidence from credit markets. Journal of Economic Dynamics and Control, vol. 43, 130-145.

[18] De Vries, G., Erumban, A., Timmer, M., Voskoboynikov, I.,\& Wu, H.X. 2012. Deconstructing the BRICs: Structural transformation and aggregate 
productivity growth. Journal of Comparative Economics, vol. 40, issue 2, 211-227

[19] McMillan, M.S. and Rodrik, D. (2011). Globalization, structural change and productivity growth. NBER Working Paper w17143

[20] Adeyinka, A., Salau, S. and Vollrath, D. (2013). Structural change in the economy of Nigeria. IFPRI Working Paper No. 24 Nigeria Strategy Support Program, July 2013.

[21] ACET. (2014). African transformation report: growth with depth. Accra, Washington, DC: African Center for Economic Transformation, ACET, pp. 22. URL: https://www.cgdev.org/sites/default/files/ACET \%20ATR \%20presentation $\% 20$ to\%20CGD

\%20042914.pdf (Date of Access: 11.01.2020).

[22] McKinsey Global Institute (2010), Lions on the move: the progress and potential of African economies. Addis Ababa: MGI, pp. 17. URL: https://www.mckinsey.com/ /media/McKinsey/Feature d\%20Insights/Middle $\% 20$ East $\% 20$ and $\% 20$ Africa/Lions $\% 20$ on $\% 20$ the $\% 20$ move/

MGI_Lions on the move african economies_Exec SS ummary.ashx (Date of Access: 15.12.2019).

[23] Hao, J., \& Hunter, W. C. (1997). A Test of the impact of financial innovation on economic growth, Managerial Finance, vol. 23(11), 64-78.

[24] Global System for Mobile Communications (GSMA). (2017). State of the Industry report Mobile Money, 2017. Retrieved from www.gsma.com/mobilemoney (Date of Access: 13.10.2019).

[25] World Economic Indicators of the World Bank. World Bank national accounts data, and OECD National Accounts data files", World Bank. Retrieved from https://data.worldbank.org/indicator/NY.GDP.PCAP.CD? locations $=$ ZG\&most recent value desc $=$ false (Date of Access: 22.11.2019). 